\title{
Erratum to: Assessment of potential non-target effects of Tetrastichus julis, a biological control agent of the cereal leaf beetle, Oulema melanopus
}

\author{
Vincent A. D. Hervet · Héctor A. Cárcamo • Lloyd M. Dosdall · \\ Terry D. Miller $\cdot$ Swaroop V. Kher
}

Published online: 29 February 2016

(C) International Organization for Biological Control (IOBC) 2016

\section{Erratum to: BioControl \\ DOI 10.1007/s10526-016-9722-7}

There was an omission in Table 3 of the original publication. The values for test species X. luteola
(U. pumila) are missing. The missing values are 25 , 25,0 , and 0 (number of replicates, $\mathrm{N}, \%$ parasitized in replications, and in larvae, resp.).

Present Address:

S. V. Kher

Alberta Agriculture and Rural Development, 7000,

113 St. NW, Edmonton, AB T6H 5T6, Canada

T. D. Miller

Aggrobiotic, 1854 Lexington Ave., Moscow, ID 83843 ,

USA

e-mail: aggrobiotic@gmail.com

H. A. Cárcamo

Agriculture and Agri-Food Canada, 5403 - 1st Ave. S., Lethbridge, AB T1J 4B1, Canada

e-mail: hector.carcamo@agr.gc.ca

L. M. Dosdall · S. V. Kher

Department of Agricultural, Food \& Nutritional Science, University of Alberta, 114 Street 89 Ave. NW, Edmonton,

AB P6G 2M7, Canada

e-mail: swaroop.kher@gov.ab.ca 